\title{
Association of autonomic nervous system functions with immune response and prognosis in acute ischemic stroke patients
}

\author{
Akut iskemik inmeli hastalarda otonom sinir sistemi fonksiyonlarının immun \\ yanıt ve prognoz ile ilişkisi
}

\author{
Burhanettin Çiğdem*, Özlem Kayım Yıldız, Mustafa Zahir Bakıcı, Suat Topaktaş \\ Neurology Clinic (B. Çiğdem, MD), Sivas State Hospital, TR-58030 Sivas, Department of \\ Neurology (Assist. Prof. Ö. K. Yıldız, MD, Prof. S. Topaktaş, MD), Department of Microbiology \\ (Prof. M. Z. Bakıc1, MD), Cumhuriyet University School of Medicine, TR-58140 Sivas
}

\begin{abstract}
Aim. Cerebrovascular disease is the most commonly encountered condition which causes serious mortality and morbidity in neurological practice. It has been reported that heart rate variability declines in a cerebrovasculer disease, which shows that autonomic functions are affected. Autonomic nervous system has a significant role in monitoring immune status and controlling inflammation. Similarly, there are studies reporting that immune system is affected during acute phase of cerebrovascular diseases. In the present study, our aim was to investigate the effect of autonomic nervous system on immune response and prognosis in acute ischemic cerebrovascular diseases. Method. 44 patients with middle cerebral artery infarction and 44 healthy controls were included in this study. Autonomic nervous system was evaluated using a methodology analysing the heart rate variability based on frequency. In order to evaluate the effects on immun system, serum levels of interleukin $1 \beta$, interleukin 6 , tumor necrosis factor alfa and interleukin 10 were measured on the $1^{\text {st }}, 3^{\text {rd }}, 7^{\text {th }}$ and $10^{\text {th }}$ day by ELISA. Prognosis was evaluated by Rankin scale after 3 months. Results. Compared to the controls, low frequency power in normalized units (LFnu) was found to be high, high frequency power in normalized units (HFnu) was found to be low and ratio of LFnu/HFnu was found to be high in the patients group. The increase being more marked in left middle cerebral artery infarctions, interleukin- 6 level were increased on the $10^{\text {th }}$ day and interleukin-10 level was decreased at all days compared to baseline in all patients. Interleukin-1 $\beta$ and tumor necrosis factor $\alpha$ levels were lower in all patients but the decrease was more pronounced in patients having left middle cerebral artery infarction. There was no difference between the Rankin scores of the patients having right and left middle cerebral artery infarction. Conclusions. Ischemic cerebrovascular disease is associated with an effect on immune system. This impaired immun response can be correlated both with a decreased parasympathetic activity and an increased sympathetic activity particularly in patients with middle cerebral artery infarctions.
\end{abstract}

Keywords: Stroke, heart rate variability, interleukin-1 $\beta$, interleukin-6, interleukin-10, tumor necrosis factor alfa

\section{Özet}

Amaç. Serebrovasküler hastalık nöroloji pratiğinde en sık karşılaşılan ve ciddi morbidite ve mortaliteye sebep olan bir durumdur. Serebrovasküler hastalıkta otonom fonksiyonlarda etkilenmeyi gösteren kalp hızı değişkenliğinde azalma olduğu bildirilmektedir. Otonom sinir sistemi immun durumun monitörize edilmesinde ve inflamasyonun kontrolünde önemli rol oynar. Benzer şekilde serebrovasküler hastalıkların akut döneminde immün sistemin de etkilendiğini gösteren çalışmalar mevcuttur. Amacımız akut iskemik serebrovasküler hastalıklarda otonom sinir sistemi fonksiyonunun immun yanıt ve prognoza etkisini araştırmaktır. Yöntem. Çalışmaya orta serebral arter infarktı olan 44 hasta ve 44 sağlıklı birey alınmıştır. Otonom sinir sistemi frekansa dayalı kalp hızı değişkenliği analiz yöntemiyle değerlendirilmiştir. İmmün sistem etkilenmesini değerlendirmede $1,3,7$ ve 10. günlerde ELİSA yöntemiyle serum interlökin-1 $\beta$, interlökin- 6 , tümör nekrozis faktör $\alpha$ ve interlökin-10 düzeyleri çalışıldı. Prognoz 3 ay sonra Rankin skoru ile değerlendirildi. Bulgular. Hastalarda kontrollerle karşılaştırıldığında Düşük Frekanslı Güç Normalize Ünit (LFnü) yüksek, Yüksek Frekanslı Güç Normalize Ünit (HFnü) düşük ve 
LFnü/HFnü oranı ise yüksek bulundu. Sol orta serebral arter infaktlarında daha belirgin olmak üzere tüm hastalarda 10. günde İnterlökin-6 seviyesinde artış, İnterlökin-10 seviyesinde ise başlangıçtan itibaren tüm günlerde düşüş görüldü. İnterlökin-1 $\beta$ ve tümör nekrozis faktör $\alpha$ seviyeleri sol orta serebral arter infaktlarında daha belirgin olmak üzere tüm hastalarda düşüktü. Rankin skorları arasında farklılık bulunmadı. Sonuç. İskemik serebrovasküler hastalık immün sistem etkilenmesi ile birliktedir. Özellikle orta serebral arter infaktlarında ortaya çıkan bu bozulmuş immun yanıt, azalmış parasempatik aktivite yanında artmış sempatik aktiviteyle ilişkilendirilebilir.

Anahtar sözcükler: İnme, kalp hızı değişkenliği, interlökin-1 $\beta$, interlökin-6, interlökin-10, tümör nekrozis faktör $\alpha$

Geliş tarihi/Received: May 12, 2012; Kabul tarihi/Accepted: September 14, 2012

\section{*Corresponding author:}

Dr. Burhanettin Çiğdem, Nöroloji Kliniği, Sivas Devlet Hastanesi, TR-58030 Sivas. E-mail: drbcigdem@gmail.com

\section{Introduction}

Autonomic nervous system (ANS) is an important part of the nerve system that regulates the involuntary operation and functions of effector organs [1, 2]. Cardiac complications such as arrhythmias, ischemic heart failure or sudden death are observed frequently after an acute stroke. It has been reported that changes in parasympathetic functions along with increased sympathetic activity plays a role in the occurence of such complications [3]. As a two-way communication channel between the brain and the immune system, ANS plays an important role for the brain to monitor the immune system and control inflammation. The initial response of the brain to inflammation is regulated by activation of autonomic nervous system pathways [4]. Classically, the two components of ANS have antagonistic but complementary functions. In regulating natural immunity, sympathetic and parasympathetic systems have an effect that supresses proinflammatory cytokine expression [4, 5]. At the early stage of inflammation, afferent vagus nerve fibers send signals to the brain to induce immunomodulatory responses. Afferent vagal nerve regulates inflammation by inhibiting proinflammatory cytokine release. The said function of afferent vagal nerve is defined as the cholinergic anti-inflammatory role. Sympathetic induction manages supression of proinflammatory cytokine release through $\beta$ adrenoreceptor mechanism and vagal nerve stimulation through nicotinic acetylcholine receptor containing $\alpha 7$ subunit [4-9]

Heart rate variability (HRV) is defined as the variation of the time intervals between two heartbeats and it is a useful indicator in evaluating ANS. Heart rate variability has been reported to descrease after acute ischemic stroke $[10,11]$. HRV is measured through beatto-beat heart rate analysis. These records are carried out by ECG. Simple measurements are carried out through trase or by a computer using a special software. Spectral analysis method was used in our study. In this method, variance and distribution of R-R values are shown as a function of frequency. Low frequency power in normalized units shows sympathetic activity, high frequency power in normalized units shows parasympathetic activity and LFnu/HFnu ratio is an indicative of sympathovagal balance [12, 13]. Clinical and experimental studies have shown that insular cortex at middle cerebral artery (MCA) watershed area is the most important cortical area in sympathetic and parasympathetic cardiovascular regulation $[14,15]$. Autonomic functions have been reported to be affected in patients having MCA infarction [3]. The aim of the present study is to investigate the relation of affected autonomic functions with hemispheric localization, proinflammatory and anti-inflammatory cytokine expression and prognosis. 


\section{Materials and Methods}

44 patients hospitalized at Cumhuriyet University, Medical Faculty, Neurology Clinic with a diagnosis of MCA watershead area ischemic infarction and 44 individuals matched for age and gender as controls were included in this study. Those having a disease affecting ANS, using medicines, having atrial fibrillation, previous stroke, transient ischemic attack, infection supported by clinical or laboratory findings, malignancy, inflammatory disease or a serious renal, hepatic or cardiac failure were excluded from the study. PC based high resolution electrocardiography system (Kardiosis ars-LP, Tepa A.S. Ankara, Turkey) was used at KHD Cumhuriyet University, Medical Faculty, Department of Neurology Autonomous Laboratory. All those in the patient and control groups were prevented from consuming substances such as tea, coffee and cigarette and performing exercise that could lead to sympathetic activation. Individuals were allowed to rest at least 20 minutes before conducting the tests. Recordings were carried out through imaging studies lasting 5 minutes in average within 3-10 days after the stroke when the patient was at rest at a room prepared specifically for imaging.

Recording was carried out by using 7 electrodes, one of which was a grounded electrode, at $X, Y$ and $Z$ planes. $X$ electrode was placed on the intercostal space in the armpit area, $\mathrm{Y}+$ electrode was placed on the 5th costal area on the midclavicular line, Y- electrode was placed over the interclavicular area, $Z+$ electrode was placed at the level of interventricular septum and Z- electrode was placed on dorsal side at the level of Z+ electrode . Spectrum fluctuations of the individuals were calculated using Kardiosis ArsLP Analysis system program. Average reference signals were obtained by HRV analysis. After assessing the reference signal, R-R intervals were measured. In calculating R-R intervals, reference signal was moved on the recording to find the maximum point of the correlation coefficient. Correlation coeffecient was regarded as 0.98 . If maximum values were above the threshold value (0.98), this was regarded as $\mathrm{R}$ wave. At the end of the process, a graphic showing beat rate at horizontal axis and $\mathrm{R}-\mathrm{R}$ interval between each beat vertical axis in millisecond was obtained, and power graphic and parameters were determined using spectrum analysis. Depending on the hemisphere of the infraction, patients were divided into two groups and serum interleukin-1 $\beta$ (IL-1 $\beta$ ), interleukin-6 (IL-6), interleukin-10 (IL-10) and tumor necrosis factor $\alpha$ (TNF $\alpha$ ) levels were measured during hospitalization and on the 3rd, 7th and 10th days. In the study, Assaypro brand (AssayMax Human EI2200-1, EI1006-1, EI3010-1,ET2010-1) ELISA kits were used. Kits were used in accordance with the user manuals at the Microbiology Department. Samples were evaluated using Triturus Grifolds full automatic MIKROELISA equipment. Locations of lesions were determined through computed brain tomography during hospitalization and on the 3rd and 5th days. "The National Institutes of Health Stroke Scale "(NIHSS) was administered during hospitalization while Rankin scale was administered 3 months after hospitalization to determine functional loss caused by the disease.

\section{Statistical analaysis}

Data were loaded onto the SPSS (Ver: 14.0) program. Mann-Whitney U test was used in order to evaluate the significance of a difference between two averages. In the tables, data are stated as average \pm standard deviation and number of subjects are given as $\%$. The level of significance was taken as 0.05 .

\section{Results}

Of 44 patients included in the study, 22 had right MCA infarction and 22 had left MCA infarction. In terms of age and gender, there was no difference between the groups. The general average of NIHSS scale scores of the patients was $8.36 \pm 2.63$. NIHSS scale score was found to be $8.23 \pm 2.91$ in those having right MCA infarction and 8.50 2.3 in those having left MCA infarction. In terms of NIHSS scale scores, there was no difference between those having right and left MCA infarctions. Compared to those in the control 
group, LFnu value and LFnu/HFnu ratio were increased and HFnu value was decreased in those having MCA infarction (Table 1).

Table 1. Comparion of LFnu, HFnu and LFnu/HFnu values of the patients.

\begin{tabular}{llll}
\hline Groups & Patient & Control & P value \\
\hline LFnu & $67.17 \pm 13.73$ & $60.87 \pm 7.69$ & $\mathrm{p}=0.010$ \\
HFnu & $23.17 \pm 9.29$ & $31.16 \pm 6.70$ & $\mathrm{p}<0.001$ \\
LFnu/HFnu & $3.87 \pm 2.87$ & $2.08 \pm 0.68$ & $\mathrm{p}<0.001$ \\
\hline
\end{tabular}

When LFnu/HFnu ratios of those having right and left MCA infarctions were compared, LFnu/HFnu ratio was more increased in the group having right MCA (Table 2).In all patients having MCA infarction, IL-1 $\beta$ and TNF $\alpha$ levels were decreased at all days when compared to the 1st day. IL-6 levels were decreased on the 3rd and 7th day and increased on the 10th day when compared to the 1st day. In all patients having MCA infarction, IL10 levels were decreased at all days when compared to the 1st day (Table 3). When IL-6 levels were evaluated in those having right MCA infarction, there was a decrease on the 3rd and 7th day $(\mathrm{p}=0.04)$ and an increase (even if it was not statistically significant) on the 10th day when compared to the 1st day.In those having left MSA infarction, IL-6 levels were decreased on the 3rd and 7th day and increased on the 10th day $(\mathrm{p}=0,04)$ (Table 4).When IL-10 levels were evaluated in those having left MSA infarction, there was a decrease at all days when compared to the 1 st day $(\mathrm{p}=0.04)$. There was an increase on the 7th day when compared to the 3rd and 10th days; however, this was below the level of the 1st day (Table 5). When inflammatory markers of those having right and left MSA infarctions were compared, IL-6 levels were significantly higher on the 1st day in those having right MSA infarction and on the 7th day in those having left MSA infarction. Compared to those having left MSA infarction, IL-6 levels were found to be higher in those having right MSA infarction on the 10th day.In terms of ranking scores on the 3rd month, there was no difference between those having right and left MCA infarctions.

Table 2. Comparison of LFnu, HFnu and LFnu/HFnu values of those having right MCA and left MCA infarctions.

\begin{tabular}{llll}
\hline Grups & Right & Left & P value \\
\hline LFnu & $70.91 \pm 12.53$ & $63.42 \pm 14.14$ & $\mathrm{p}>0.05$ \\
HFnu & $20.90 \pm 9.49$ & $25.44 \pm 8.72$ & $\mathrm{p}>0.05$ \\
LFnu/HFnu & $4.66 \pm 3.39$ & $3.08 \pm 2.01$ & $\mathrm{p}<0.05$ \\
\hline
\end{tabular}

Table 2. IL-1ß , TNFa, IL-6 and IL-10 levels of the patients on the 1st, 3rd, 7th and 10th days.

\begin{tabular}{lllll}
\hline Grups & IL-1 $\beta$ & TNF $\boldsymbol{\alpha}$ & IL-6 & IL-10 \\
\hline $1^{\text {st }}$ day & $2.75 \pm 5.14$ & $12.77 \pm 12.95$ & $11.19 \pm 38.38$ & $253.51 \pm 473.66$ \\
$3^{\text {rd }}$ day & $1.80 \pm 4.29$ & $9.52 \pm 9.75$ & $3.63 \pm 7.94$ & $207.69 \pm 332.19$ \\
$7^{\text {th }}$ day & $1.94 \pm 4.33$ & $11.30 \pm 10.10$ & $2.94 \pm 4.19$ & $219.19 \pm 300.55$ \\
$10^{\text {th }}$ day & $1.86 \pm 5.01$ & $9.49 \pm 10.78$ & $24.83 \pm 72.07$ & $173.96 \pm 259.66$ \\
& $\mathrm{P}=0,005$ & $\mathrm{P}=0.001$ & $\mathrm{P}=0.018$ & $\mathrm{P}=0.022$ \\
\hline
\end{tabular}

Table 4. Comparison of IL-6 values measured on the 1st, 3rd, 7th and 10th days in patients having right and left MCA infarctions.

\begin{tabular}{lll}
\hline IL-6(pg/mL) & Right MCA & Left MCA \\
\hline $1^{\text {st }}$ day & $17.65 \pm 54.07$ & $4.73 \pm 2.52$ \\
$3^{\text {rd }}$ day & $4.25 \pm 10.84$ & $3.02 \pm 3.31$ \\
$7^{\text {th }}$ day & $2.75 \pm 5.73$ & $3.14 \pm 1.78$ \\
$10^{\text {th }}$ day & $25.56 \pm 72.72$ & $24.11 \pm 73.12$ \\
& $\mathrm{P}=0.040$ & $\mathrm{P}=0.044$ \\
\hline
\end{tabular}


Table 5. Comparison of IL-10 values measured on the 1st, 3rd, 7th and 10th days in patients having right and left MCA infarctions.

\begin{tabular}{lll}
\hline IL-10 $(\mathbf{p g} / \mathbf{m L})$ & Right MCA & Left MCA \\
\hline $1^{\text {st }}$ day & $218.87 \pm 394.93$ & $288.14 \pm 548.56$ \\
$3^{\text {rd }}$ day & $217.49 \pm 327.06$ & $197.89 \pm 344.65$ \\
$7^{\text {th }}$ day & $227.80 \pm 336.66$ & $210.57 \pm 267.34$ \\
$10^{\text {th }}$ day & $218.48 \pm 320.15$ & $129.42 \pm 177.21$ \\
& $\mathrm{P}=0.813$ & $\mathrm{P}=0.040$ \\
\hline
\end{tabular}

\section{Discussion}

Inflammation plays an important role in the development ischemic damage and escalation of inflammation in the central nervous system $[16,17]$. Many studies have reported that cardiac autonomic function is impaired in patients with ischemic stroke [11, 18]. It has been suggested that autonomic cardiovascular failure is associated with the impairment of parasympathetic function in patients with stroke [19]. In some articles it was shown that there is a cortical asymmetry in regulation of hearth rate and other cardiyovascular functions. In these studies right insular cortex stimulation was responsible for increase in sympathetic cardiovascular functions and left insular cortex was responsible for increase in parasympathetic activity [20-25]. In the present study, it was found that the autonomic nervous system functions were affected in favor of sympathetic system, which was more evident in right hemisphere lesions in patients with MCA infarction. Insular cortex lying below frontoparietal and superior temporal operculum located at the watershed area of ANS has been shown to be an important cortical area playing a role in sympathetic and parasympathetic cardiovascular regulation $[13,15]$. It is thought that the results obtained in the present study do not relate to isolated lesions of the insular cortex as the patients with AND infarction did not only have lesions of the insular cortex. It has been reported that there is an excessive IL-1 and TNF $\alpha$ release during brain ischemia [26, 27]. While the possible reason of low IL-1 and TNF $\alpha$ levels could be increased sympathetic activity in our study, other reasons could be the individual characteristics of the patients, medicines used for treatment and sensitivity of the kits used. Many cytokines such us unfractionated heparin TNF $\alpha$ may decrease cytokine production [28]. In a study, IL-10 levels were reported to decrease just after stroke, increase on the 7th day, decrease again on the 14th day while IL-6 levels were reported to increase significantly between the 1st and the 10th days when compared to the controls [29]. In an experimental study of rats having MCA obstructions there was an increase in IL-6 levels 3 hours after the obstructions and 12 hours later the levels were at the maximal point and it remained high for nearly 24 hours [30]. In an other study of 113 patients with lacunar infarcts it is shown that there is an increase in IL-6 and TNF alfa levels and this increase is a marker ofworse prognosis[31]. In some studies decrease of IL-10 levels after subcortical and lacunar stroke was related with worse prognosis and in animal models increase of IL-10 levels after focal stroke was related with neuroprotective activity and reduce in brain damage $[32,33]$.

In our study, IL-6 level was found to be high on the 10th day in all patients having MCA infarction, especially in those having left hemisphere lesions. In our study, we found that the balance between IL-6 and IL-10 levels, showing an antagonistic correlation in inflammation control under normal conditions, disappeared [29]. The increase in IL-6 levels on the 10th day in patients with MCA infarction, which was more evident in left hemisphere lesions, can be associated with supressed parasympathetic activity. Increase in IL-10 levels at all days in left hemisphere lesions can not be associated with suppressed parasympathetic activity as parasympathetic system does not have any effect on IL-10 level [4]. In our study, parasympathetic activity was suppressed in lesions of both hemisphere with a more evident suppression in right hemisphere lesions. Sympathetic activity was increased in lesions of both hemisphere while the said increase was more in 
right hemisphere lesions. The results obtained suggest that sympathetic system, along with parasympathetic system, could play a role in managing immunity and inflammation. Having suppressed parasympathetic function but increased sympathetic activity in right hemisphere lesions and having a proinflammatory (IL-6) and antiinflammatory (IL-10) balance not imparied much in right hemisphere lesions when compared to the one in left hemisphere lesions can be associated with increased sympathetic activity. The results obtained can be associated with different action mechanisms such as cholinergic antiinflammatory pathway and $\alpha 7$ sununit levels and functions of nicotinic acetylcholine receptors [6]. Future studies evaluating ANS function, cytokine levels, $\alpha 7$ sununit levels and functions of nicotinic acetylcholine receptors together may yield important information in clarifying the issue.

\section{References}

1. Waxman GS. Korrelatif Nöroanatomi. Yıldırım M. (çeviri), Nobel Tıp Kitabevi, İstanbul 2002; 248-63.

2. Snell SR. Klinik Nöroanatomi. Yıldırım M. (çeviri), Nobel Tıp Kitabevi, İstanbul 2000; 459-78.

3. Mıhçı E, Kardelen F, Yılmaz N, Dora B, Balkan S. Hemisferik enfarktlı hastalarda kalp hızı değişkenliğinin tilt testi sırasında değerlendirilmesi. Türk Serebrovasküler Hastalıklar Dergisi 2007; 13: 81-5.

4. Pavlov VA, Tracey KJ. Neural regulators of innate immune responses and inflammation. Cell Mol Life Sci 2004; 61: 2322-31.

5. Nance DM, Sanders VM. Autonomic innervation and regulation of the immune system (1987-2007). Brain Behav Immun 2007; 21: 736-45.

6. Pavlov VA, Tracey KJ. The cholinergic anti-inflammatory pathway Brain Behav Immun 2005; 19: 493-9.

7. Goehler LE, Gaykema RP, Hansen MK, Anderson K, Maier SF, Watkins LR. Vagal immune-to-brain communication: a visceral chemosensory pathway. Auton Neurosci 2000; 85: 49-59.

8. Czura CJ, Tracey KJ. Autonomic neural regulation of immunity. J Intern Med 2005; 257: 156-66.

9. Tracey KJ. Physiology and immunology of the cholinergic antiinflammatory pathway. J Clin Invest 2007; 117: 289-96.

10. Van Ravenswaaiji-Arts CMA, Kollee LAA, Hopman JCW, Stoelinga GBA, Vangeijn HP. Heart rate variability. Ann Intern Med 1993; 188: 436-47.

11. Barron SA, Rogovski Z, Hemli J. Autonomic consequences of cerebral hemisphere infarction. Stroke 1994; 25: 113-6.

12. Akselrod S. Components of heart rate variabilitity: Basic studies.In: Malik M, Camm AJ. (Eds). Heart rate varibililiy. New York. Futura 1995; pp: 147-63.

13. Maliani A. Association of heart rate variability components with physiological regulatory mechanisms. In: Malik M, Camm AJ (Eds). Heart rate variabililiy. NewYork. Futura 1995; pp: 147-63.

14. Tokgözoğlu SL, Batur MK, Top uoglu MA, Saribas O, Kes S, Oto A. Effects of stroke localization on cardiac autonomic balance and sudden death. Stroke 1999; 30: 1307-11.

15. Cheshire WP Jr, Saper CB. The insular cortex and cardiac response to stroke. Neurology 2006; 66: 1296-7.

16. Özdağ F, Bek S, Ulaş ÜH, Eroğlu E, Gökçil Z, Demirkay Ş, Şengül A, Vural O. Erken dönem deneysel strokta sitokinler. Gülhane Tip Dergisi 2003; 45: 114-6.

17. Rodríguez-Yáñez M, Castillo J. Role of inflammatory markers in brain ischemia. Curr Opin Neurol 2008; 21: 353-7.

18. Korpelainen JT, Sotaniemi KA, Huikuri HV, Myllyä VV. Abnormal heart rate variability as a manifestation of autonomic dysfunction in hemispheric brain infarction. Stroke 1996; 27: 2059-63.

19. Korpelainen JT, Sotaniemi KA, Suominen K, Tolonen U, Myllylä VV. 
Cardiovascular autonomic reflexes in brain infarction. Stroke 1994; 25: 787-92.

20. Naver HK, Blomstrand C, Wallin G. Reduced heart rate variability after rightsided stroke. Stroke 1996; 27: 247-251.

21. Colivicchi F, Bassi A, Santini M. Cardiac autonomic deragrement and arrhythmias in right-sided stroke with insular involvement. Stroke 2004; 35: 2094-2098.

22. .Oppenheimer S. The anatomy and physiology of cortical mechanisms of cardiac control. Stroke 1993; 24(suppl I): I-3-I-5.

23. Oppenheimer SM, Gelb A, Girvin JP. Cardiovascular effects of human insular cortex stimulation. Neurology 1992; 42: 1727-1732.

24. Yoon B-W, Morillo CA, Cechetho D F. Cerebral hemispheric lateralization in cardiac autonomic control. Arc Neurol 1997; 54: 741-744.

25. Hilz M.J, Dütsch M, Perine K. Hemispheric influence on autonomic modulation and baroreflex sensitivity. Ann Neurol 2001; 49: 575-584.

26. Pantoni L, Sarti C, Inzitari D. Cytokines and cell adhesion molecules in cerebral ischemia: experimental bases and therapeutic perspectives. Arterioscler Thromb Vasc Biol 1998; 18: 503-13.

27. Intiso D, Zarrelli MM, Lagioia G, Di Rienzo F, Checchia De Ambrosio C, Simone P, Tonali P, Cioffi Dagger RP. Tumor necrosis factor alpha serum levels and inflammatory response in acute ischemic stroke patients. Neurol Sci 2003; 24: 390-6.

28. Chamorro A, Cervera A, Castillo J, Dávalos A, Aponte JJ, Planas AM. Unfractionated heparin is associated with a lower rise of serum vascular cell adhesion molecule-1 in acute ischemic stroke patients. Neurosci Lett 2002; 328: 229-32.

29. Perini F, Morra M, Alecci M, Galloni E, Marchi M, Toso V. Temporal profile of serum anti-inflammatory and pro-inflammatory interleukins in acute ischemic stroke patients. Neurol Sci 2001; 22: 289-96.

30. Wang X, Yue TL, Young PR, Barone FC, Feuerstein GZ. Expression of interleukin-6, c-fos, and zif268 mRNA in rat ischemic cortex. J Cereb Blood Flow Metab 1995; 15: 166-71.

31. Castellanos, M, Castillo, J, Garcia, M.M, Leira, R, Chamorro A, Davalos A. Inflammation-mediated damage in progressing lacunar infarctions: a potential therapeutic target. Stroke 2002; 33: 982-7.

32. Vila N, Castillo J, Dávalos A, Esteve A. Levels of anti-inflammatory cytokines and neurological worsening in acute ischemic stroke. Stroke 2003; 34: 671-675.

33. Dietrich WD, Busto R, Bethea JR. Postischemic hypothermia and IL-10 treatment provide long-lasting neuroprotection of CA1 hippocampus following transient global ischemia in rats. Exp Neurol 1999; 158: 444-450. 